\title{
Toll-Like Receptor 4 in Experimental Kidney Transplantation: Early Mediator of Endogenous Danger Signals
}

\author{
Tobias Bergler ${ }^{a}$ Ute Hoffmann ${ }^{a, b}$ Elisabeth Bergler ${ }^{a}$ Bettina Jung ${ }^{a}$ \\ Miriam C. Banas ${ }^{a}$ Stephan W. Reinhold ${ }^{a}$ Bernhard K. Krämer ${ }^{c}$ Bernhard Banas ${ }^{a}$ \\ ${ }^{a}$ Department of Internal Medicine II, University Medical Center Regensburg and b Department of Nephrology, \\ Krankenhaus Barmherzige Brüder, Regensburg, and ' ${ }^{~ V}$. Medizinische Klinik, Universitätsklinikum Mannheim, \\ Universität Heidelberg, Mannheim, Germany
}

\section{Key Words}

Allogeneic kidney transplantation - Chemokines •

Fibrinogen $\cdot$ Innate immunity $\cdot$ Macrophages

\begin{abstract}
The role of toll-like receptors (TLRs) has been described in the pathogenesis of renal ischemia/reperfusion injury, but data on the expression and function of TLR4 during renal allograft damage are still scarce. We analyzed the expression of TLR4 in an experimental rat model 6 and 28 days after allogeneic kidney transplantation in comparison to control rats and rats after syngeneic transplantation. On day 6 , a significant induction in TLR4 expression - restricted to the glomerular compartment - was found in acute rejecting allografts only. TLR4 expression strongly correlated with renal function, and TLR4 induction was accompanied by a significant increase in CC chemokine expression within the graft as well as in urinary CC chemokine excretion. TLR4 induction may be caused by an influx of macrophages as well as TLR4expressing intrinsic renal cells. Fibrinogen deposition in renal allografts correlated with renal TLR4 expression and may act as a potent stimulator of chemokine release via TLR4 activation. This study provides, for the first time, data about the
\end{abstract}

precise intrarenal localization and TLR4 induction after experimental kidney transplantation. It supports the hypothesis that local TLR4 activation by endogenous ligands may be one pathological link from unspecific primary allograft damage to subsequent chemokine release, infiltration and activation of immune cells leading to deterioration of renal function and induction of renal fibrosis.

Copyright $\odot 2012$ S. Karger AG, Base

\section{Introduction}

Despite the availability of HLA matching, routine cross-matching and potent immunosuppression, acute renal allograft rejection after kidney transplantation is still characterized by the recruitment of monocytes/macrophages, $\mathrm{T}$ and $\mathrm{B}$ lymphocytes and rapid deterioration of renal function $[1,2]$. Subpopulations of inflammatory cells are guided towards specific renal microenvironments in a complex cascade of interactions between adhe-

T.B. and U.H. contributed equally to this study.

\section{KARGER}

Fax +4161306 1234

E-Mail karger@karger.ch

www.karger.com
(C) 2012 S. Karger AG, Basel

$1660-2129 / 12 / 1214-0059 \$ 38.00 / 0$

Accessible online at:

www.karger.com/nee
Dr. med. Tobias Bergler

Klinik und Poliklinik für Innere Medizin II - Nephrologie

Universität Regensburg, Franz-Josef-Strauss-Allee 11

DE-93053 Regensburg (Germany)

E-Mail tobias.bergler@klinik.uni-regensburg.de 
sion molecules, chemokines and chemokine receptors [3-5]. Furthermore, cell type-specific toll-like receptors (TLRs) were found to be important for the activation of chemokines and chemoattraction or priming of $\mathrm{T}$ cells [6-9].

TLRs are innate immune system receptors, which recognize specific molecular patterns present on invading microorganisms and thus are important in various kidney diseases $[10,11]$. TLRs can also be activated by endogenous molecules $[12,13]$, such as heat shock protein 60 or 70 [14-16], fibronectin [17, 18], soluble hyaluronan [1921] and fibrinogen [22]. In a model of hepatic ischemiareperfusion injury (IRI), definitive evidence was found that endogenous TLR4 ligands are critical in the pathogenesis of liver IRI [23]. In a model of chronic allograft dysfunction, the functional relevance of TLR2/4 and their two major signaling pathways (MyD88 and TRIF) was demonstrated after endogenous incubation [24]. In a model of kidney IRI, a significant increase in TLR4 expression by tubular epithelial cells and infiltrating leukocytes was demonstrated [25] and it was shown that TLR4 acts as a sentinel for acute IRI-mediated renal damage [26]. Using a model of unilateral ureteral obstruction, it has recently been shown that TLR4-deficient mice displayed reduced fibrosis and that TLR4 blockade might be a therapeutic target for preventing renal fibrosis [27].

In renal transplantation, most of the data focus on the role of TLR4 polymorphisms. In one study, renal transplant recipients with TLR4 polymorphism presented a lower risk of posttransplantation atherosclerotic events and acute allograft rejection if they received donor grafts heterozygous for the Asp299Gly or Thr399Ile TLR4 allele [28]. An additional study established the relevance of TLR4 polymorphisms in acute rejection of kidney transplants [29].

However, in contrast to IRI, only few data exist about TLR4 expression, localization and activation of after allogeneic versus syngeneic kidney transplantation. We therefore used an experimental rat transplantation model of acute rejection to investigate the time course of TLR4 induction after kidney transplantation under standardized conditions. Our study was aimed at answering the following questions: (1) is TLR4 induction due to allogeneicity or to transplantation per se? (2) What are the time course and intrarenal localization of TLR4 expression? (3) Are endogenous ligands, such as fibrinogen, which are released during transplantation, potent activators of TLR4 and subsequent CC chemokine release, which is crucial for recruitment and enhancement of immune response by attraction of inflammatory cells?

\section{Materials and Methods}

\section{Animals and Renal Transplantation}

Animal experiments were performed following the NIH principles for laboratory animal care and the German laws on animal protection. Study approval was given by the inspecting authority (Regierung der Oberpfalz). Male Brown Norway rats served as donors and Lewis rats as recipients (Charles River Laboratories, Sulzfeld, Germany). The rats (200-250 g) were kept under conventional housing and diet conditions. Abbreviations, numbers, treatment regimens, histopathological diagnoses adapted to the Banff '97 classification for renal allograft damage and the corresponding renal function of the different groups are summarized in table 1. Detailed protocols for renal transplantation have been previously published by our group [30, 31]. Briefly, allograft-dependent damage (Brown Norway rats as donors, Lewis rats as recipients) was compared with potential alterations after syngeneic transplantation (Lewis rats as donors and recipients) on postoperative days (PODs) 3, 6, 28. Cyclosporine (CsA, $5 \mathrm{mg} / \mathrm{kg}$, Neoral; Novartis, Basel, Switzerland, administered once daily by gavage) was used as immunosuppression; naïve rats without CsA treatment served as controls. Additional alterations after unilateral nephrectomy with or without CsA treatment and IRI were performed (data not shown). During transplantation, the left kidneys were explanted, flushed with cold saline and transplanted orthotopically by endto-end anastomosis of the vessels and the ureter. Cold- and warmischemia times were approximately 35 and $30 \mathrm{~min}$. Nephrectomy of both native kidneys was performed at the time of transplantation also in the syngeneic group. The transplanted groups were treated with CsA $(\mathrm{KTx}+\mathrm{CsA})$ or left without immunosuppression $(\mathrm{KTx}-\mathrm{CsA})$. The latter group only underwent the 6-day protocol. After euthanasia, the kidneys were divided into quarters and fixed in paraffin or snap-frozen in $\mathrm{N}_{2}$ and stored at $-80^{\circ} \mathrm{C}$.

In the 6-day protocol, the rats were monitored in metabolic cages on PODs 0,3 and 6 and in the 28-day experimental protocol, on PODs $0,7,14,21$ and 28. Histopathological diagnoses adapted to the Banff '97 classification [1] of the kidney specimens were made by renal pathologists.

RNA Isolation, Reverse Transcription and Real-Time PCR

Total RNA was extracted from frozen tissue sections in peqGOLD TriFast (Peqlab, Erlangen, Germany) and reverse transcribed into cDNA as described before [30]. Primer sequences are listed in table 2 .

\section{Immunohistochemistry}

Immunohistochemistry was performed as previously described [32]. Sections were analyzed for TLR4 protein expression (monoclonal TLR4 antibody, Acris Antibodies GmbH, Hiddenhausen, Germany), CCL20 (polyclonal goat CCL20 antibody, Santa Cruz Biotechnology, Heidelberg, Germany), fibrinogen (polyclonal sheep fibrinogen antibody, AbDSeroTec, Düsseldorf, Germany), CD68 (monoclonal mouse antibody, AbDSeroTec, Düsseldorf, Germany), CD3 (polyclonal rabbit antibody, Abcam Cambridge, UK) and CD20 (polyclonal goat antibody, Santa Cruz Biotechnology). To further define the TLR4-positive cell population, paraffin-embedded allograft sections of transplanted rats were used for immunofluorescence as previously described [32]. Primary antibodies were detected by Alexa Fluor ${ }^{\circledR}$ antibodies (Invitrogen, Karlsruhe, Germany). Slides were then coverslipped 
Table 1. Experimental renal transplantation model in rats in a 6-day and a 28-day protocol: numbers of rats, histopathological classification and serum creatinine concentrations of the different groups

\begin{tabular}{lllll}
\hline & Control & synKTx & KTx - CsA & KTx + CsA \\
\hline Rats, $n$ & & & 10 & 10 \\
$\quad$ 6-day protocol & 7 & 6 & - & 12 \\
$\quad \begin{array}{l}\text { 28-day protocol } \\
\text { Histopathological classification }\end{array}$ & 7 & 4 & Banff 4 III & Banff 4 IA \\
$\quad$ 6-day protocol & Banff 1 & Banff 1 & - & Banff 1 (n = 10); Banff 4 IA (n = 2) \\
$\quad$ 28-day protocol & Banff 1 & Banff 1 & & $0.62 \pm 0.21$ \\
$\quad \begin{array}{l}\text { Serum creatinine, mg/dl } \\
\quad \text { 6-day protocol } \\
\text { 28-day protocol }\end{array}$ & $0.34 \pm 0.07$ & $0.48 \pm 0.21$ & $3.22 \pm 0.22$ & $0.37 \pm 0.04$ \\
\hline
\end{tabular}

Table 2. Primer sequences $(\mathrm{r}=\mathrm{rat})$

\begin{tabular}{lll}
\hline Gene & Forward primer & Reverse primer \\
\hline rCCL2 $(=\mathrm{MCP} 1)$ & $5^{\prime}$-tagcatccacgtgctgtctc-3' & $5^{\prime}$-tgctgctggtgattctcttg-3' \\
rCCL20 (= MIP-3 $\alpha)$ & $5^{\prime}$-caactttgactgctgcctca-3' & $5^{\prime}$-cggatctttcgacttcagg-3' \\
rCD3 & $5^{\prime}$-ggctggtgtcatcatcactg-3' & $5^{\prime}$-tcaacagcccagaaagtct-3' \\
rCD20 & $5^{\prime}$-ctgatgatccccacaggagt-3' & $5^{\prime}$-cctggaggtttctctgctg-3' \\
rCD68 & $5^{\prime}$-aatgtgtccttcccacaagc-3' & $5^{\prime}$-tgcttgtatttccgcaacag-3' \\
rFibrinogen- $\beta$ & $5^{\prime}$-cctacgacagggacaacgat-3' & $5^{\prime}$-tgtaaaggccaccccagtag-3' \\
rFibrinogen- $\gamma$ & $5^{\prime}$-gtgcgaatccatgacacaac-3' & $5^{\prime}$-tttccagatccgtcgattc-3' \\
rGAPDH & $5^{\prime}$-gtcgtggatctgacgtgcc-3' & $5^{\prime}$-gatgcctgcttcaccacctt-3' \\
rTLR4 & $5^{\prime}$-ggcagcaggtcgaattgtat-3' & $5^{\prime}$-tcaaggcttttccatccaac-3' \\
\hline
\end{tabular}

with Vectashield ${ }^{\circledR}$ Mounting Medium with DAPI (Linaris, Wertheim-Bettingen, Germany).

\section{Digital Imaging}

For analysis of TLR4 expression, 10 high-power fields per specimen were examined by two different investigators (original magnification $\times 400$, covering an area of $296 \mu \mathrm{m} \times 222 \mu \mathrm{m}$ ). Within these fields, the percentage of positive glomeruli among all detected glomeruli and positive tubuli among all detected tubuli were calculated for each specimen. We additionally noted, for each high-power field, whether positive staining was apparent in interstitia or in vessels. Mean and median values were calculated for each group.

\section{Quantification of CCL20 Protein in Urine}

Quantification of CCL20 protein in urine by Western blot analysis was performed as described before [31]. CCL20 was used as primary antibody (R\&D Systems, Minneapolis, Minn., USA, MN55413 mouse IgG1 anti-rat CCL20, $2 \mu \mathrm{g} / \mathrm{ml}$ ) and binding of the primary antibody was visualized with a peroxidase-conjugated goat anti-mouse IgG-HRP secondary antibody (1:5,000, Santa Cruz Biotechnology).
Statistical Analysis

Values are provided as means \pm SEs. Statistical analysis was performed by the nonparametric Mann-Whitney $U$ test and by univariate ANOVA. $\mathrm{p}<0.05$ was considered to be statistically significant.

\section{Results}

\section{Clinical and Histopathological Characterization of} the Different Experimental Groups

$\mathrm{KTx}+\mathrm{CsA}$ rats displayed serum creatinine levels almost twice as high as those of controls (Banff $1=$ normal) and moderate histopathological changes with typical signs of rejection on POD day 6 (Banff 4 IA = interstitial infiltration $>25 \%$ of parenchyma affected and foci of moderate tubulitis) (table 1). On POD 6, syngeneic transplantated (synKTx) rats displayed slightly elevated creatinine levels without histopathological changes (Banff 1) compared to control rats. In contrast, KTx - CsA showed severely elevated serum creatinine levels on POD 6 and signs of severe 
Fig. 1. TLR4 mRNA expression (means \pm SEMs) on PODs 6 and 28 in the different groups. ${ }^{\mathrm{a}} \mathrm{p}<0.05$ versus control, ${ }^{\mathrm{b}} \mathrm{p}<0.05$ versus $\mathrm{KTx}+\mathrm{CsA}$.

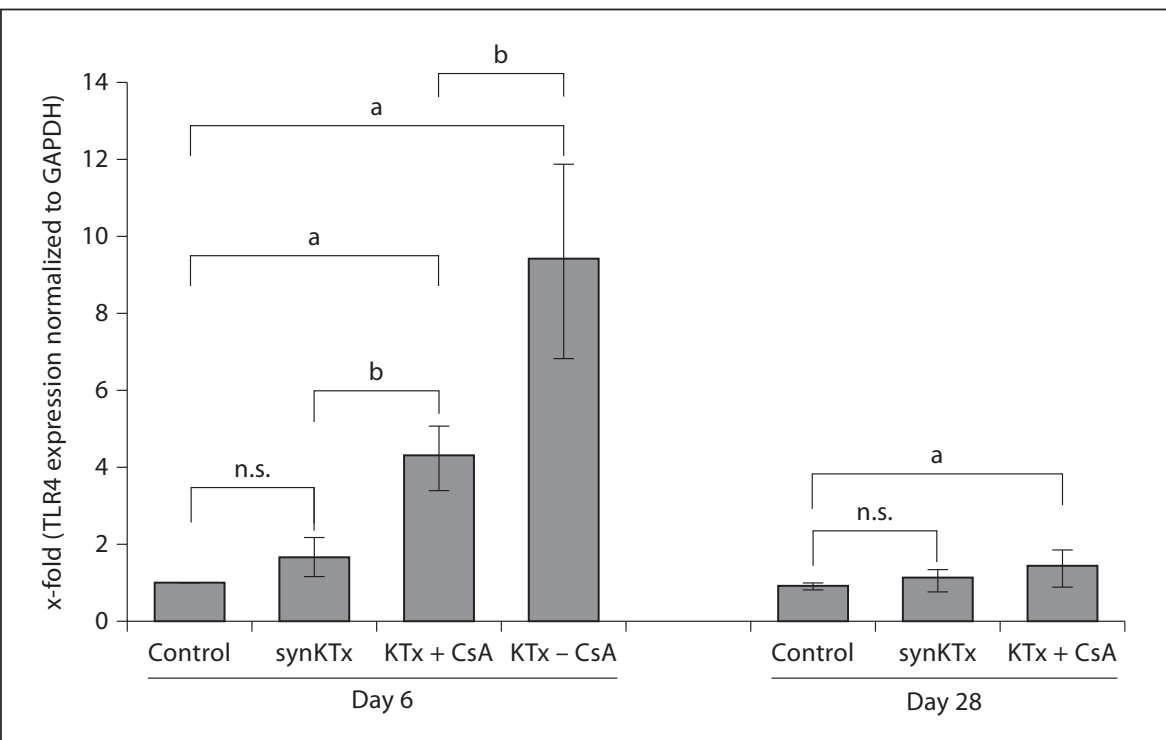

Day 6
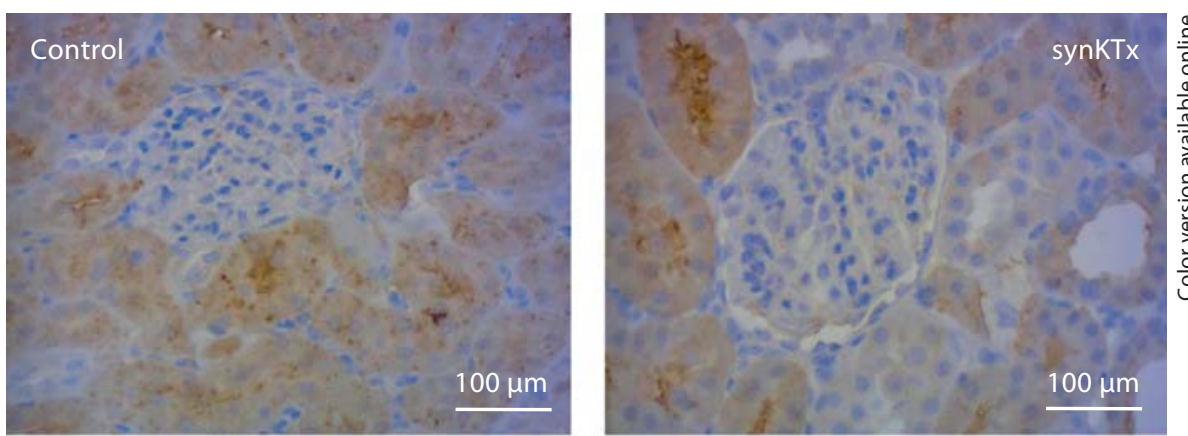
and synKTx rats, the most prominent TLR4 staining was observed in the proximal tubuli. There was no positive staining in glomeruli. In KTx + CsA rats, upregulation of TLR4 expression was also seen in the glomerular compartment (red arrows, black in the printed version) (mesangial cells, podocytes) and in the interstitium (green arrows, white in the printed version), which was more pronounced in KTx - CsA rats. Original magnification $\times$ 400.

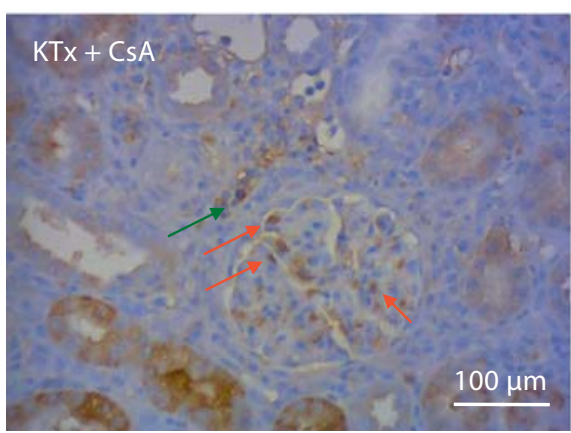

rejection (Banff $4 \mathrm{III}=$ transmural arteritis and/or arterial fibrinoid change and necrosis); all animals died within 10 days. On POD 28, there was less difference in serum creatinine and histopathological diagnoses between the remaining groups: similarly to controls and synKTx rats, 10 out of $12 \mathrm{KTx}+$ CsA rats showed normal histopathological characteristics (Banff 1); the other 2 rats showed only moderate signs of rejection (Banff 4 IA; table 1).
TLR4 mRNA Induction in an Experimental Kidney

\section{Transplantation Model}

Compared to controls, significantly upregulated TLR4 mRNA expression was only seen in KTx + CsA $(\mathrm{p}=0.02)$ and $\mathrm{KTx}-\mathrm{CsA}(\mathrm{p}=0.008)$ rats on POD 6 (fig. 1). TLR4 mRNA expression in $\mathrm{KTx}$ - CsA rats was significantly higher than in $\mathrm{KTx}+\mathrm{CsA}$ rats $(\mathrm{p}=0.004)$. In contrast, syngeneic transplantation did not alter TLR4 expression

Bergler/Hoffmann/Bergler/Jung/Banas/ Reinhold/Krämer/Banas 
Fig. 3. Quantification of glomerular (a) and tubular (b) TLR4 staining (means \pm SEs) on PODs 6 and 28. ${ }^{\mathrm{a}} \mathrm{p}<0.05$ versus control, ${ }^{\mathrm{b}} \mathrm{p}<0.05$ versus $\mathrm{KTx}+\mathrm{CsA}$.
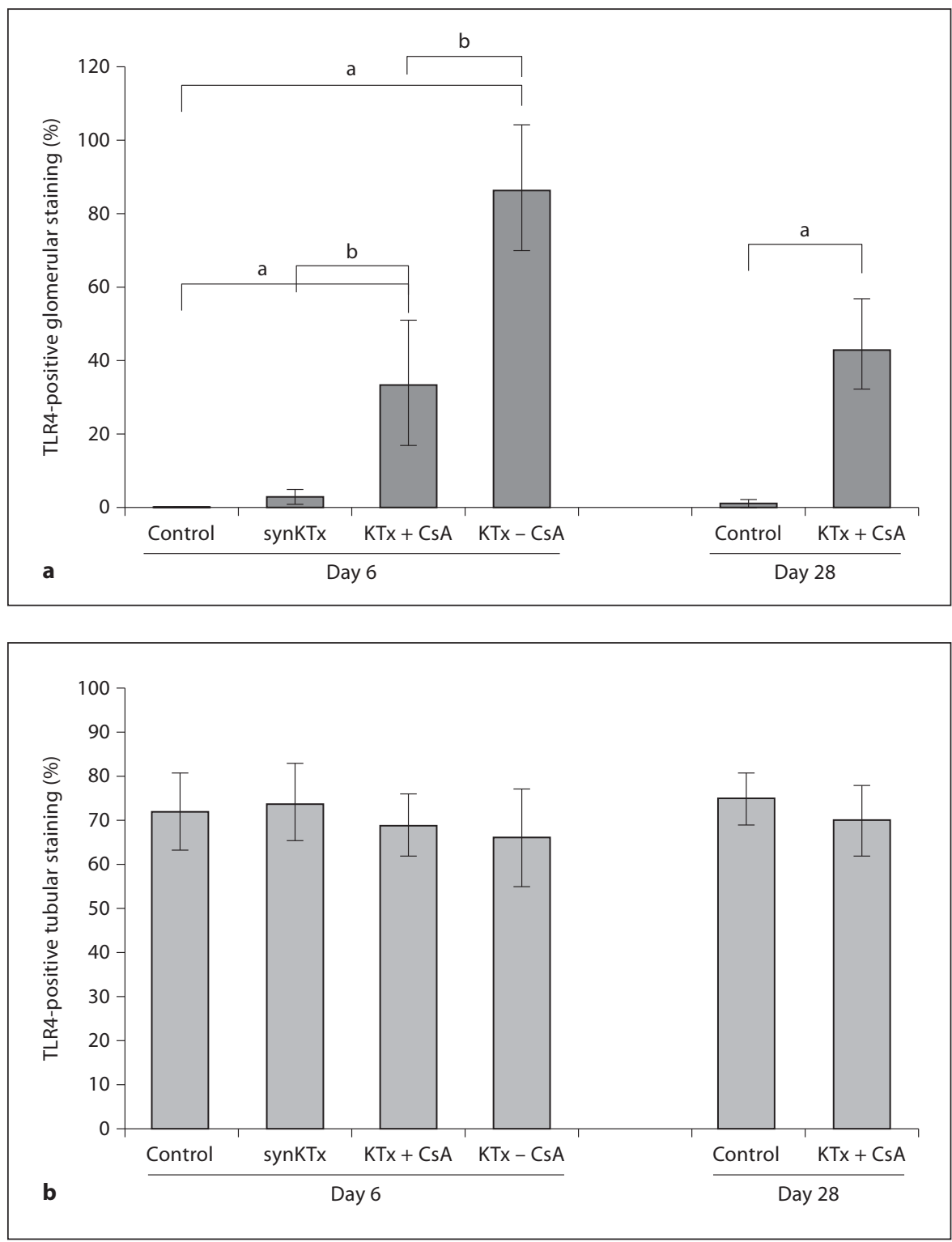

either on POD 6 or on POD 28. On POD 28, TLR4 mRNA expression in $\mathrm{KTx}+\mathrm{CsA}$ rats was still upregulated (1.4fold; $\mathrm{p}=0.05$ ) in comparison with control rats, but the expression was significantly lower than on POD $6(\mathrm{p}=$ 0.03) (fig. 1). On POD 3, a 2.5-fold TLR4 induction was seen in $\mathrm{KTx}+$ CsA rats $(\mathrm{p}=0.04)$, which was quite similar to that in synKTx rats (2.2-fold TLR4 induction; $\mathrm{p}=0.04$ ) and IRI-treated rats (2.85-fold TLR4 induction; $\mathrm{p}=0.03$; data not shown). However, no other alteration (i.e. unilateral nephrectomy with or without CsA or IRI) significantly influenced TLR4 expression on POD 6 or 28 (data not shown).
Localization and Quantification of TLR4 Induction by Immunohistochemistry

On POD 6 and 28, there was a prominent TLR4 staining in arterial vessel walls in all groups whereas no TLR4 staining could be detected in veins. In kidneys of control rats and synKTx rats, TLR4 staining was restricted to the proximal tubuli within the cortex and the outer medullary stripe. With the exception of the visceral/parietal aspects of Bowman's capsule, TLR4 expression was absent in glomeruli or the inner medulla (fig. 2). In contrast, $\mathrm{KTx}+\mathrm{CsA}$ rats displayed a milder TLR4 staining in glomeruli and in the interstitium (fig. 2). KTx - CsA 

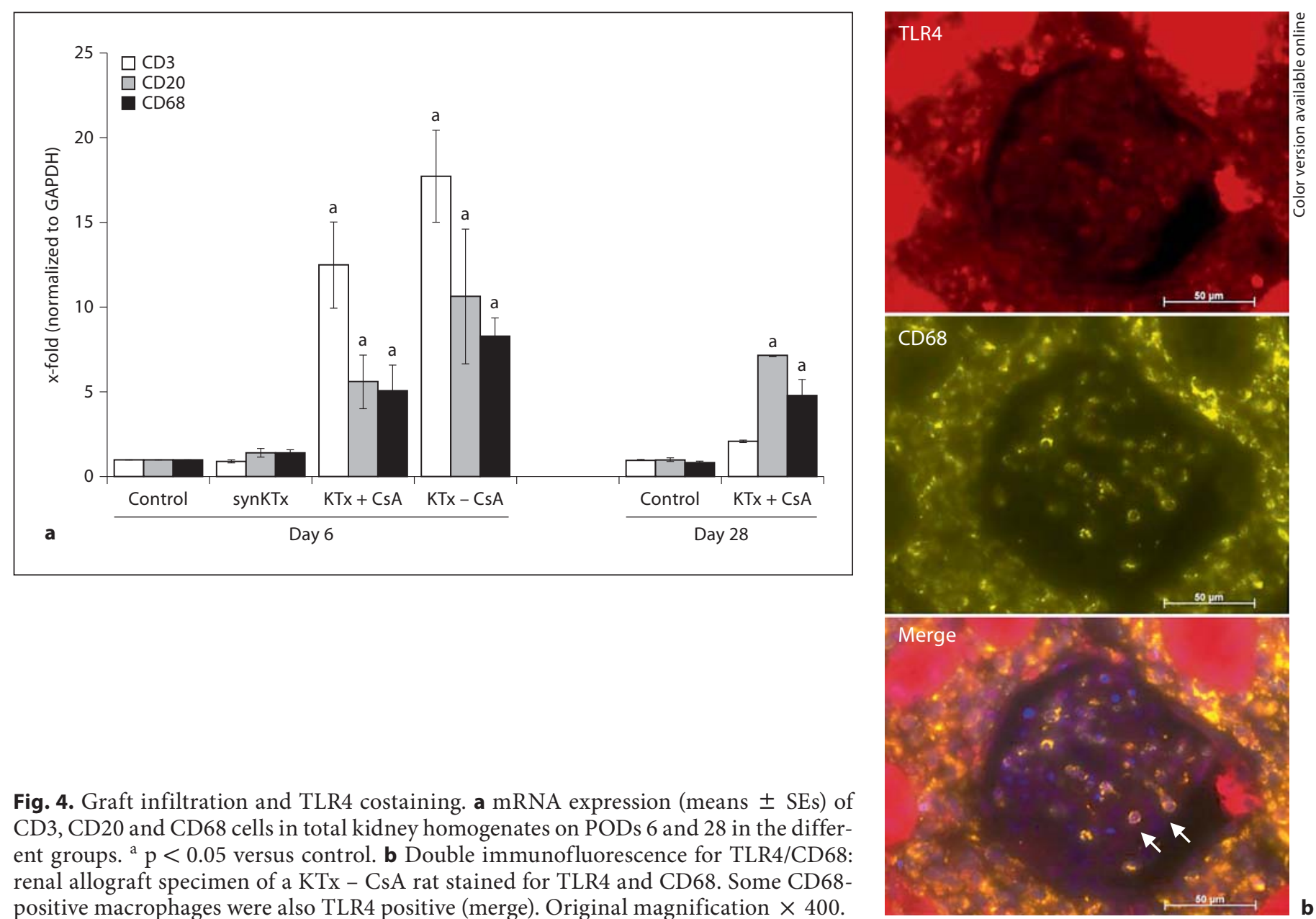

Fig. 4. Graft infiltration and TLR 4 costaining. a mRNA expression (means \pm SEs) of CD3, CD20 and CD68 cells in total kidney homogenates on PODs 6 and 28 in the different groups. ${ }^{a} \mathrm{p}<0.05$ versus control. b Double immunofluorescence for TLR4/CD68: renal allograft specimen of a KTx - CsA rat stained for TLR4 and CD68. Some CD68positive macrophages were also TLR4 positive (merge). Original magnification $\times 400$.

and 28. In total kidney homogenates, CD3, CD20 and CD68 mRNA expression was significantly elevated in $\mathrm{KTx}+\operatorname{CsA}(\mathrm{p}<0.01)$ and KTx - CsA rats $(\mathrm{p}<0.001)$ on POD 6, compared to control and in contrast to synKTx rats (fig. 4a). On POD 28, significantly elevated CD20 and CD68 expression was still found in KTx + CsA rats ( $\mathrm{p}<$ 0.01 ). Additional analysis of relative CD68-positive staining in the different groups by Meta View ${ }^{\circledR}$ software confirmed these data: control on POD 6: 2.00\%; synKTx $10.78 \%$; KTx \pm CsA on POD 6: 74.41\%, KTx \pm CsA on POD 28: 23.59\% (data not shown).

To further specify the TLR4-positive cell population, we stained serial slides for TLR4 and CD3, CD20 and CD68 and performed double immunofluorescence: TLR4 was mainly expressed on CD68-positive monocytes/ macrophages (fig. 4b).

\section{Quantification of Infiltrating Cell Populations to the} Graft

CD3, CD20 and CD68 mRNA expression was examined in total kidney homogenates of all groups on POD 6 


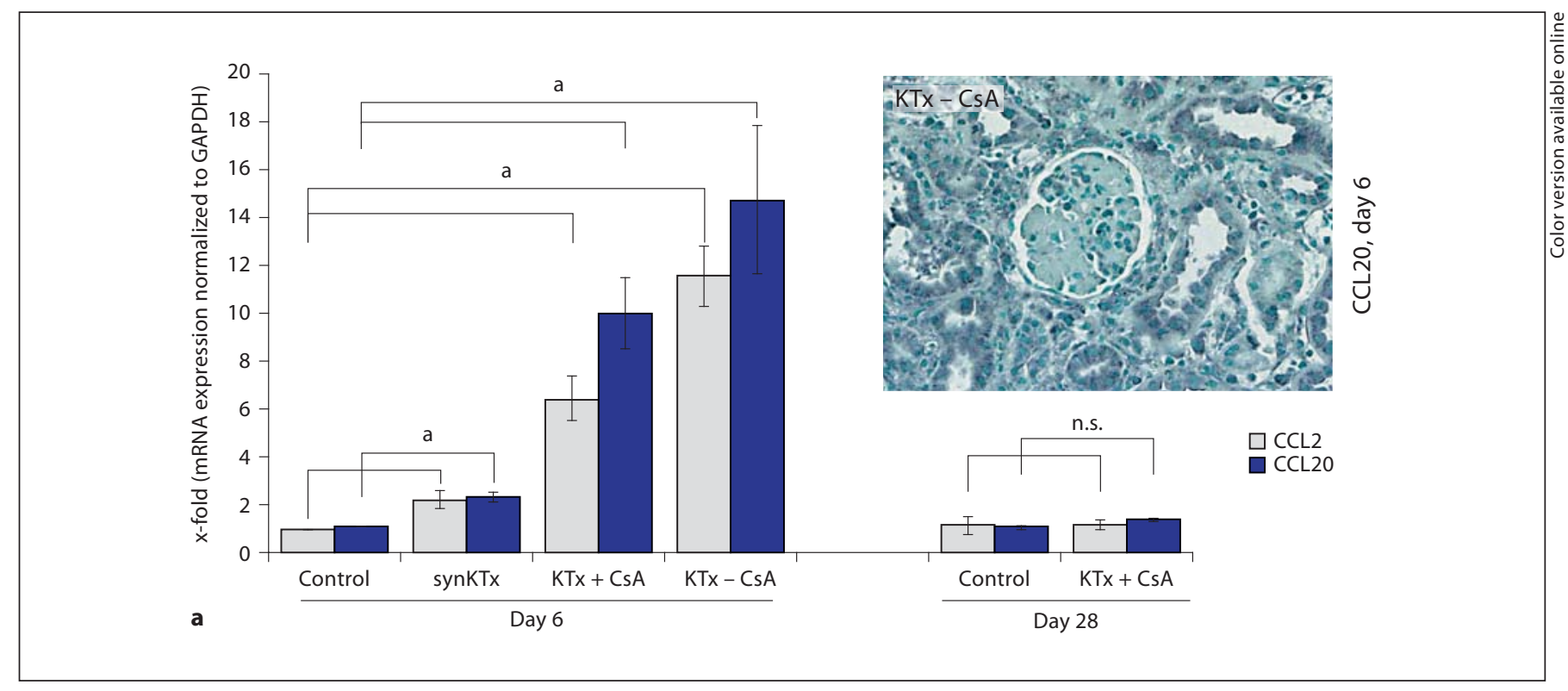

Fig. 5. CC chemokine induction. a mRNA expression (means \pm SEs) of CCL2 and CCL20 on PODs 6 and 28 in the different groups. ${ }^{a} \mathrm{p}<0.05$ versus control. Immunohistochemistry: in KTx - CsA rats, CCL20-positive staining was found in glomerular cells, tubuli, interstitial infiltrates and endothelial cells. b Western blot analysis of CCL20 urinary protein on PODs 3 and 6 in control rats without CsA treatment, $\mathrm{KTx}+\mathrm{CsA}$ and $\mathrm{KTx}-\mathrm{CsA}$ $(n=6)$ and Western blot analysis of CCL20 urinary protein on POD 28 in control rats with and without CsA treatment (Control + CsA and Control - CsA) and KTx + CsA rats. TLR4 expression is shown in comparison with actin (loading control). Representative results of 3 independently repeated experiments are shown.

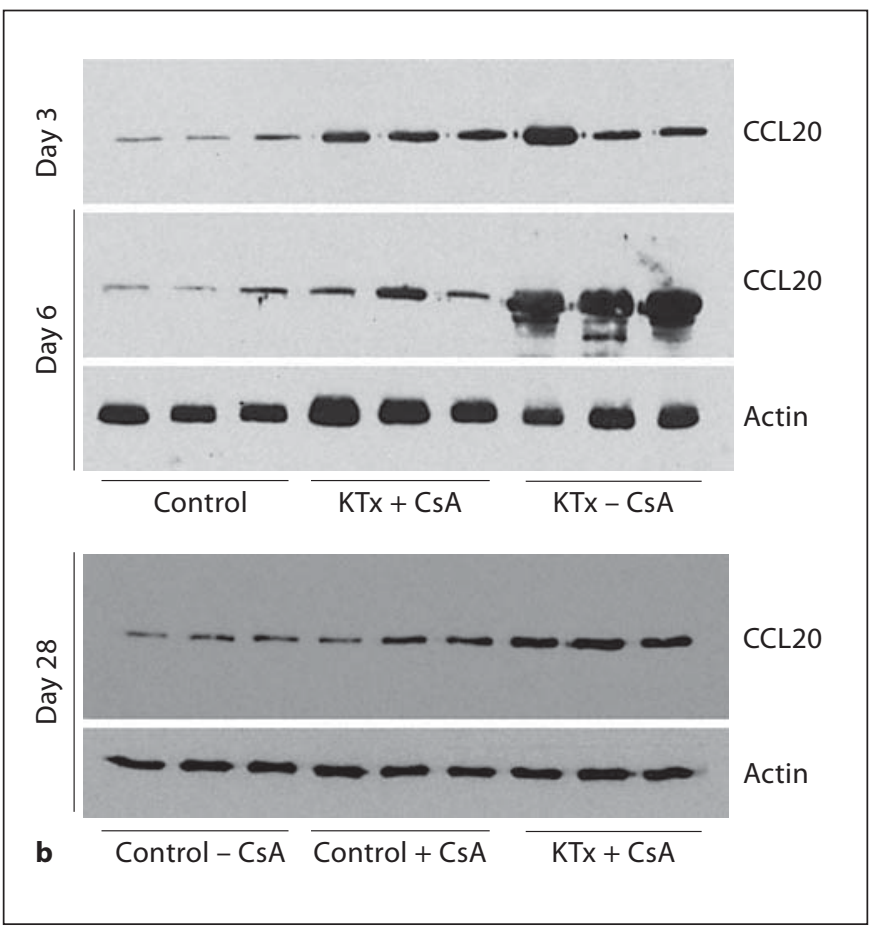

Chemokine Expression in the Allograft

We detected a significant increase in CCL2 and CCL20 mRNA expression in KTx + CsA $(\mathrm{p}<0.001)$ and KTx CsA rats $(\mathrm{p}<0.01)$ on POD 6 (fig. 5a) compared to controls. CCL2 expression in KTx - CsA was significantly higher than in KTx + CsA ( $\mathrm{p}=0.01)$. On POD 28, both $\mathrm{CC}$ chemokines reached baseline levels without any sig-

nificant differences. On POD 6, CCL2 and CCL20 mRNA were moderately upregulated in synKTx rats $(\mathrm{p}=0.04)$. Besides CCL20, its receptor CCR6 was also significantly upregulated in $\mathrm{KTx}+\mathrm{CsA}(\mathrm{p}=0.005)$ and $\mathrm{KTx}-\mathrm{CsA}$ rats $(\mathrm{p}=0.0007)$ on POD 6 (data not shown), with significantly higher CCR6 expression in KTx - CsA rats ( $\mathrm{p}=$ 0.02). CCR6 expression in KTx + CsA rats was still sig- 


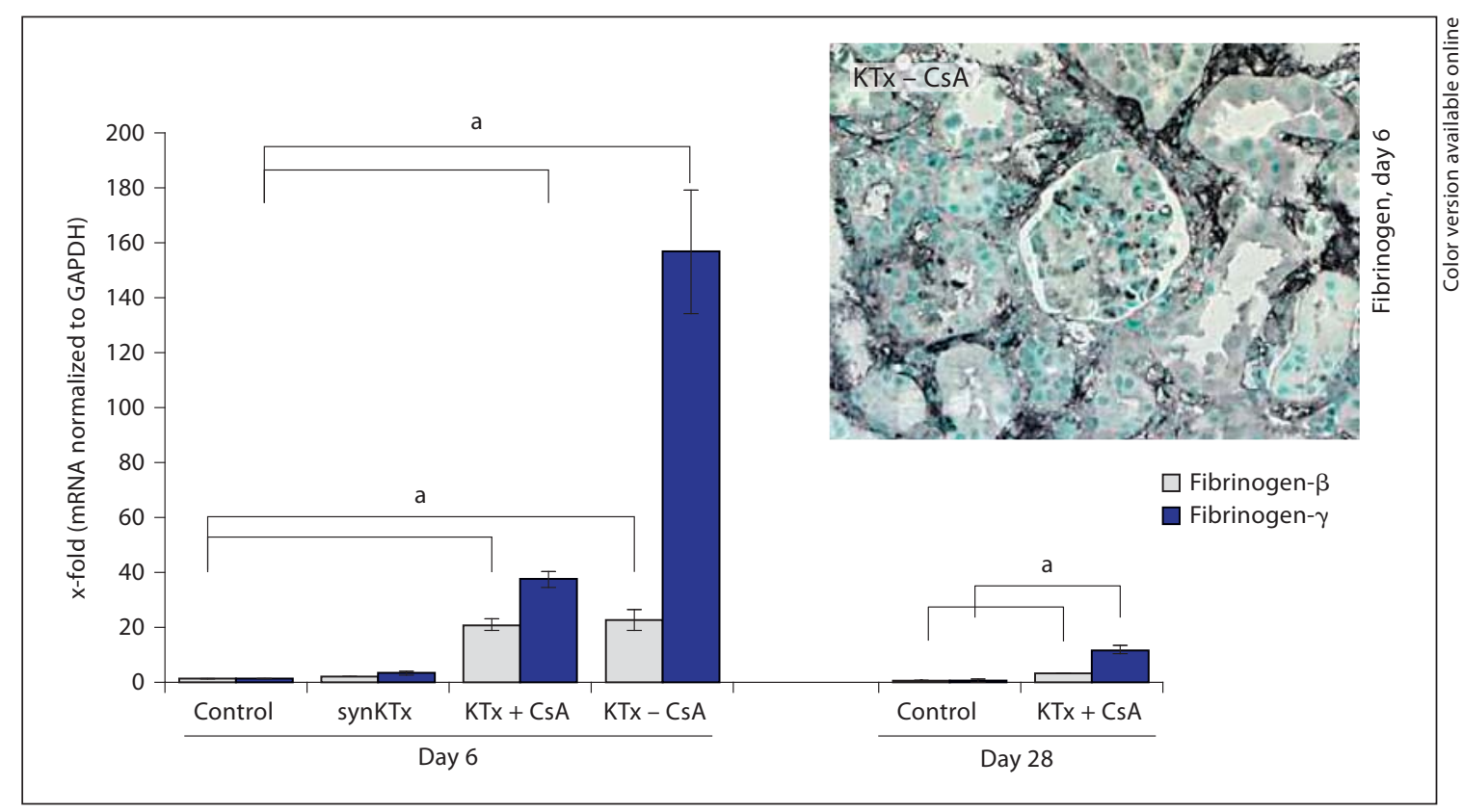

Fig. 6. Fibrinogen expression and fibrinogen deposition. mRNA expression (means \pm SEs) of fibrinogen- $\beta$ and $-\gamma$ in total kidney homogenates on PODs 6 and 28 in the different groups. ${ }^{a} p<0.05$ versus control. Immunohistochemistry: in KTx - CsA rats, fibrinogen deposition was found intraglomerularly and interstitially.

nificantly elevated on POD 28 ( $\mathrm{p}=0.003$; data not shown). Using immunohistochemistry, we found that in control, but also in synKTx animals, positive CCL20 staining on POD 6 as well as on POD 28 was restricted to Bowman's capsule and some vascular endothelial cells. In contrast, prominent accumulation of CCL20-positive cells was detected mainly in interstitial infiltrates and in the glomerular compartment of KTx + CsA and KTx - CsA rats (fig. 5a). Serial slides confirmed that CCL20 expression colocalized with TLR4-positive cells.

\section{Western Blot Analysis of Urinary CCL20 Excretion}

In comparison with control rats, we detected a marked increase in CCL20 protein in the urine of KTx + CsA and $\mathrm{KTx}$ - CsA rats already on POD 3 (fig. 5b). Urinary CCL20 protein of KTx - CsA rats was markedly higher than in $\mathrm{KTx}+\mathrm{CsA}$ rats and these differences were even more pronounced on POD 6. On POD 28, we compared control \pm CsA with $\mathrm{KTx}+\mathrm{CsA}$ rats and detected only a slight increase in urinary CCL20 protein level in KTx + CsA rats.

\section{Fibrinogen Deposition after Allogeneic Kidney}

Transplantation

A significant increase in fibrinogen- $\beta$ and $-\gamma$ mRNA expression in KTx \pm CsA rats was found on POD 6 com- pared to controls (fig. 6). The expression level of fibrinogen$\gamma$ was significantly higher in KTx + CsA rats. In synKTx rats, there was only a trend towards increased fibrinogen- $\beta$ and $-\gamma$ expression. On POD 28 after allogeneic transplantation, fibrinogen- $\beta$ and $-\gamma$ deposition was still significantly upregulated; however, in comparison with POD 6, a significant decrease was found ( $p=0.002)$. The immunohistochemical findings were in accordance with the detected mRNA expression levels. In allografts of the transplanted rats, a marked increase in fibrinogen-positive staining in the peritubular arteries within glomeruli and interstitial infiltrates could be demonstrated mainly in the KTx - CsA group. In serial slides, fibrinogen deposition matched with TLR4 staining, especially in the glomerular, periglomerular and peritubular parts (data not shown). In synKTx rats, only mild fibrinogen staining was found (data not shown).

\section{Discussion}

In the present study, we examined the time course and localization of TLR4 after experimental kidney transplantation, correlated these data with renal function and further focused on functional consequences of TLR4 activation. 
Significantly induced TLR4 mRNA expression was found only after allogeneic transplantation. TLR4 mRNA expression was elevated on POD 6 and decreased towards POD 28 in KTx \pm CsA.

Immunohistochemistry displayed high but unmodified TLR4 protein expression in renal tubular cells and highly inducible TLR4 staining within glomeruli in KTx \pm CsA rats. These rats also displayed tubulointerstitial infiltrates with TLR4-positive cells and immunofluorescence characterized these cells mainly as CD68-positive macrophages. Whereas TLR4 expression on tubular cells was previously reported to be important during ascending urinary infections [33], our finding of upregulated TLR4 within glomeruli in renal allogeneic, but not syngeneic transplants is new. Both intrinsic renal cells (e.g. mesangial cells, podocytes and vascular endothelial cells) and infiltrating macrophages seem to contribute to TLR4 expression in allograft rejection. The expression profile of infiltrating cells within the allografts with an ongoing CD20/68 pattern typically for B-cells and macrophages on POD 28 in KTx + CsA rats as well as the CD68-TLR4 double staining proving the presence of TLR4-positive macrophages favors the importance of infiltrating cells for TLR4 expression. However, immunohistochemical data on TLR4 induction not only in the interstitial but also within the glomerular compartment stress the importance of renal intrinsic cells after acute rejection for ongoing TLR4 induction. The relevance of infiltrating and intrinsic renal cells to TLR4 induction after acute rejection still lacks clarity.

Continuative experiments in an IRI mouse model with chimeric mice suggested that TLR4 signaling in intrinsic more than infiltrating cells plays a crucial role in renal damage after kidney ischemia for $22 \mathrm{~min}$ [25]. Additional work by Leemans et al. [34] with chimeric mice also postulated that TLR2 expressed on the renal parenchyma plays a crucial role in the induction of inflammation and injury after IRI. TLR4 is considered as a key molecule of innate immunity involved in cell survival as well as IRI, where it has been intensively examined $[25,26,35$, 36]. As the ischemia times were short in our model ( 35 min of cold and $30 \mathrm{~min}$ of warm ischemia time), a significant contribution of IRI to TLR4 expression beyond POD 5 should be limited because renal TLR4 expression after allogeneic transplantation displayed a different time course: whereas TLR4 expression due to IRI is seen at earlier time points (POD 3) and disappears or is much lower on POD $5[25,26]$, we observed a peak of TLR4 expression on POD 6 with decreasing TLR4 expression on POD 28.

TLR4 after Allogeneic Transplantation
Thus, the impact of IRI on TLR4 expression levels in our renal transplantation model might be lower than the contribution of intrinsic renal- and graft-infiltrating CD68-positive macrophages. This is stressed by the similar TLR4 induction in KTx + CsA, KTx - CsA, synKTx and IRI-treated rats on POD 3 and the striking differences at later time points, where allogeneic transplantation seems to be a sustained trigger. TLR4 induction correlated with both renal function and local chemokine synthesis: TLR4 activation was accompanied by marked induction of CCL2 and CCL20. Both chemokines were significantly upregulated in renal allografts, especially in allograft rejection. These data are in line with the finding that TLR4 is linked to the expression of proinflammatory cytokines and chemokines [25]. Chemokines like CCL2 are known to recruit and activate leukocytes [37] and thus can mediate allograft rejection [38-40]. The relevance of CCL2 was already underlined by data showing that high levels of donor-derived CCL2 are associated with poor outcome in murine islet transplantation [41] and by findings on the differences in CCL2 expression between allografts and isografts 7 days after islet transplantation. The parallel induction of TLR4 and CCL2/CCL20 after allogeneic transplantation in a model of acute rejection stresses the relevance of these data because markedly increased CCL2 expression was also seen in human renal allografts with acute rejection [42]. CCL20 was not only induced within the kidney but was also excreted into the urine of transplanted rats in amounts that correlate with the severity of allograft rejection. Therefore, transplanted rats with almost normal renal function and without significant allograft rejection on POD 28 only showed a slight increase in CCL20 urinary protein concentration. These data support previous findings suggesting that CCL20 is as a sensitive urinary marker of allograft rejection [43, 44]. Because of the induction of CCL2 and CCL20 chemokines after TLR4 induction and their known role for recruitment and enhancement of immune response by attraction of inflammatory cells monitoring, TLR4 expression may be a useful tool for monitoring renal function and a novel marker of acute rejection. However, one study analyzing human allograft biopsies for TLR4 staining could not correlate TLR4 expression and renal function [45]. One explanation for this discrepancy might be the time course of TLR4 expression after kidney transplantation. In our model, TLR4 expression peaked on POD 6 and the other study analyzed protocol biopsies from human allografts at least 6 weeks after transplantation.

Nephron Exp Nephrol 2012;121:e59-e70 e67 
So far, our data demonstrate that TLR4 and CCL2 and CCL20 induction was restricted to the KTx groups. These data were analyzed in an acute rejection model whereas data on the relevance of TLR4 expression and chronic allograft dysfunction (CAD) have been intensively studied in a mouse model [24]. Wang et al. [31] showed that the innate immune system, and especially TLR 2 and TLR4, is involved in CAD development. We also examined the contribution of TLR2 in an acute rejection model and found marked upregulation of TLR2 after experimental renal transplantation, an observation that was confirmed in acute rejection of human allografts. In contrast, no induction of other TLRs typically expressed intracellularly, such as TLR3 or TLR9, was detected.

Influx of CD68-positive macrophages could be found in synKTx rats only by immunohistochemical software analysis whereas KTx rats not only displayed a brighter staining degree but also induced mRNA expression. These data are in line with a previous study that demonstrated significantly higher TLR4 expression on circulating monocytes in patients with acute rejection after liver transplantation [46].

Additional experiments were designed to test the role of the endogenous TLR4 ligand fibrinogen. We found significantly induced fibrinogen deposition (in peritubular arteries, within the glomeruli and interstitial infiltrates) matching TLR4 localization as shown by serial slides. Additionally, we were able to detect significantly induced local fibrinogen mRNA synthesis after allogeneic transplantation. We have previously demonstrated in cultured podocytes that fibrinogen is a potent TLR4 activator, and that podocytes release chemokines after fibrinogen incubation in a TLR4-dependent manner [47], a mechanism potentially important for other renal cell types as well. The time course of fibrinogen expression in our kidney transplantation model was in accordance with an exper- imental cardiac transplantation model, in which expression of fibrinogen-like protein 2 peaked at day 7 [48]. The relevance of fibrinogen deposition after human kidney transplantation was previously demonstrated [49]. Besides these transplantation models, the substantial contribution of fibrinogen was characterized in different models of glomerulonephritis [50-53]. The significantly induced fibrinogen mRNA synthesis after allogeneic transplantation might be regarded as a hint for an ongoing contribution of fibrinogen to allograft damage in an acute rejection model.

In summary, after experimental kidney transplantation, TLR4 expression was found be induced in the allogeneic setting, but not by transplantation per se and in a time course rather different from that after IRI. TLR4 expression correlated with renal allograft function and subsequent CC chemokine expression in the graft as well with CC chemokine release into the urine. Early activation of TLR4 by fibrinogen as part of innate immunity could be the first response to tissue injury prior to activation of the adaptive immune system $[54,55]$.

\section{Acknowledgements}

This work was supported by the Else Kröner-Fresenius-Stiftung to T.B., the Regensburger Forschungsförderung in der Medizin (ReForM A project to T.B./, ReForM B project to U.H.) and the Deutsche Forschungsgemeinschaft (BA 2137 to B.B.).

We thank Mrs. Stefanie Ellmann and Mrs. Alexandra Wilhelm for their excellent technical assistance.

\section{Disclosure Statement}

The authors have no conflict of interest/competing interests with regard to the present study.
References
Racusen LC, Solez K, Colvin RB, Bonsib SM, Castro MC, Cavallo T, Croker BP, Demetris AJ, Drachenberg CB, Fogo AB, Furness P, Gaber LW, Gibson IW, Glotz D, Goldberg JC, Grande J, Halloran PF, Hansen HE, Hartley B, Hayry PJ, Hill CM, Hoffman EO, Hunsicker LG, Lindblad AS, Yamaguchi Y: The Banff 97 working classification of renal allograft pathology. Kidney Int 1999;55:713723.

2 el-Sawy T, Fahmy NM, Fairchild RL: Chemokines: directing leukocyte infiltration into allografts. Curr Opin Immunol 2002;14: 562-568.

\footnotetext{
3 Colvin BL, Thomson AW: Chemokines, their receptors, and transplant outcome. Transplantation 2002;74:149-155.

-4 Hancock WW, Wang L, Ye Q, Han R, Lee I: Chemokines and their receptors as markers of allograft rejection and targets for immunosuppression. Curr Opin Immunol 2003; 15:479-486.

5 Segerer S, Nelson PJ, Schlöndorff D: Chemokines, chemokine receptors, and renal disease: from basic science to pathophysiologic and therapeutic studies. J Am Soc Nephrol 2000;11:152-176.
} 
-6 Hertz CJ, Wu Q, Porter EM, Zhang YJ, Weismuller KH, Godowski PJ, Ganz T, Randell SH, Modlin RL: Activation of Toll-like receptor 2 on human tracheobronchial epithelial cells induces the antimicrobial peptide human beta defensin-2. J Immunol 2003;171: 6820-6826.

7 Iwasaki A, Medzhitov R: Toll-like receptor control of the adaptive immune responses. Nat Immunol 2004;5:987-995.

8 Rakoff-Nahoum S, Paglino J, Eslami-Varzaneh F, Edberg S, Medzhitov R: Recognition of commensal microflora by toll-like receptors is required for intestinal homeostasis. Cell 2004;118:229-241.

-9 Schnare M, Barton GM, Holt AC, Takeda K, Akira S, Medzhitov R: Toll-like receptors control activation of adaptive immune responses. Nat Immunol 2001;2:947-950.

10 Akira S, Takeda K: Functions of toll-like receptors: lessons from $\mathrm{KO}$ mice. C R Biol 2004;327:581-589.

- 11 Anders HJ, Banas B, Schlöndorff D: Signaling danger: toll-like receptors and their potential roles in kidney disease. J Am Soc Nephrol 2004;15:854-867.

$\checkmark 12$ Beg AA: Endogenous ligands of Toll-like receptors: implications for regulating inflammatory and immune responses. Trends Immunol 2002;23:509-512.

-13 Wallin RP, Lundqvist A, More SH, von BA, Kiessling R, Ljunggren HG: Heat-shock proteins as activators of the innate immune system. Trends Immunol 2002;23:130-135.

- 14 Friedland JS, Shattock R, Remick DG, Griffin GE: Mycobacterial 65-kD heat shock protein induces release of proinflammatory cytokines from human monocytic cells. Clin Exp Immunol 1993;91:58-62.

15 Retzlaff C, Yamamoto Y, Hoffman PS, Friedman H, Klein TW: Bacterial heat shock proteins directly induce cytokine mRNA and interleukin-1 secretion in macrophage cultures. Infect Immun 1994;62:5689-5693.

16 Tsan MF, Gao B: Endogenous ligands of Tolllike receptors. J Leukoc Biol 2004;76:514519.

-17 Okamura Y, Watari M, Jerud ES, Young DW, Ishizaka ST, Rose J, Chow JC, Strauss JF III: The extra domain A of fibronectin activates Toll-like receptor 4. J Biol Chem 2001;276: 10229-10233.

18 Saito S, Yamaji N, Yasunaga K, Saito T, Matsumoto S, Katoh M, Kobayashi S, Masuho Y: The fibronectin extra domain A activates matrix metalloproteinase gene expression by an interleukin-1-dependent mechanism. J Biol Chem 1999;274:30756-30763.

19 Noble PW, McKee CM, Cowman M, Shin HS: Hyaluronan fragments activate an NFkappa B/I-kappa B alpha autoregulatory loop in murine macrophages. J Exp Med 1996; $183: 2373-2378$
20 Termeer C, Benedix F, Sleeman J, Fieber C, Voith U, Ahrens T, Miyake K, Freudenberg M, Galanos C, Simon JC: Oligosaccharides of hyaluronan activate dendritic cells via toll-like receptor 4. J Exp Med 2002;195:99111.

-21 Termeer CC, Hennies J, Voith U, Ahrens T, Weiss JM, Prehm P, Simon JC: Oligosaccharides of hyaluronan are potent activators of dendritic cells. J Immunol 2000;165:18631870.

22 Smiley ST, King JA, Hancock WW: Fibrinogen stimulates macrophage chemokine secretion through toll-like receptor 4 . J Immunol 2001;167:2887-2894

23 Zhai Y, Qiao B, Shen XD, Gao F, Busuttil RW, Cheng G, Platt JL, Volk HD, Kupiec-Weglinski JW: Evidence for the pivotal role of endogenous toll-like receptor 4 ligands in liver ischemia and reperfusion injury. Transplantation 2008;85:1016-1022.

24 Wang S, Schmaderer C, Kiss E, Schmidt C, Bonrouhi M, Porubsky S, Gretz N, Schaefer L, Kirschning CJ, Popovic ZV, Grone HJ: Recipient Toll-like receptors contribute to chronic graft dysfunction by both MyD88and TRIF-dependent signaling. Dis Model Mech 2010;3:92-103.

$25 \mathrm{Wu}$ H, Chen G, Wyburn KR, Yin J, Bertolino P, Eris JM, Alexander SI, Sharland AF, Chadban SJ: TLR4 activation mediates kidney ischemia/reperfusion injury. J Clin Invest 2007;117:2847-2859.

26 Pulskens WP, Teske GJ, Butter LM, Roelofs JJ, van der PT, Florquin S, Leemans JC: Tolllike receptor-4 coordinates the innate immune response of the kidney to renal ischemia/reperfusion injury. PLoS One 2008; 3:e3596.

27 Pulskens WP, Rampanelli E, Teske GJ, Butter LM, Claessen N, Luirink IK, van der PT, Florquin S, Leemans JC: TLR4 promotes fibrosis but attenuates tubular damage in progressive renal injury. J Am Soc Nephrol 2010; 21:1299-1308.

28 Palmer SM, Burch LH, Mir S, Smith SR, Kuo PC, Herczyk WF, Reinsmoen NL, Schwartz DA: Donor polymorphisms in Toll-like receptor- 4 influence the development of rejection after renal transplantation. Clin Transplant 2006;20:30-36.

- 29 Hwang YH, Ro H, Choi I, Kim H, Oh KH, Hwang JI, Park MH, Kim S, Yang J, Ahn C: Impact of polymorphisms of TLR4/CD14 and TLR3 on acute rejection in kidney transplantation. Transplantation 2009;88:699705.

30 Hoffmann U, Bergler T, Rihm M, Pace C, Krüger B, Rümmele P, Stoelcker B, Banas B, Männel DN, Krämer BK: Upregulation of TNF receptor type 2 in human and experimental renal allograft rejection. Am J Transplant 2009;9:675-686.
31 Hoffmann U, Bergler T, Rihm M, Pace C, Krüger B, Jung B, Reinhold SW, Farkas S, Rümmele P, Krämer BK, Banas B: Impact of Toll-like receptor 2 expression in renal allograft rejection. Nephrol Dial Transplant 2011;26:1080-1087.

32 Hoffmann U, Segerer S, Rümmele P, Krüger B, Pietrzyk M, Hofstadter F, Banas B, Krämer BK: Expression of the chemokine receptor CXCR3 in human renal allografts - a prospective study. Nephrol Dial Transplant 2006;21:1373-1381.

33 Tsuboi N, Yoshikai Y, Matsuo S, Kikuchi T, Iwami K, Nagai Y, Takeuchi O, Akira S, Matsuguchi T: Roles of toll-like receptors in C-C chemokine production by renal tubular epithelial cells. J Immunol 2002;169:20262033.

- 34 Leemans JC, Stokman G, Claessen N, Rouschop KM, Teske GJ, Kirschning CJ, Akira S, van der PT, Weening JJ, Florquin S: Renalassociated TLR2 mediates ischemia/reperfusion injury in the kidney. J Clin Invest 2005;115:2894-2903.

-35 Wang H, Li ZY, Wu HS, Wang Y, Jiang CF, Zheng QC, Zhang JX: Endogenous danger signals trigger hepatic ischemia/reperfusion injury through toll-like receptor $4 /$ nuclear factor-kappa B pathway. Chin Med J (Engl) 2007;120:509-514.

36 Wu HS, Zhang JX, Wang L, Tian Y, Wang H, Rotstein O: Toll-like receptor 4 involvement in hepatic ischemia/reperfusion injury in mice. Hepatobiliary Pancreat Dis Int 2004;3: 250-253.

37 Laudanna C, Kim JY, Constantin G, Butcher E: Rapid leukocyte integrin activation by chemokines. Immunol Rev 2002;186:37-46.

38 Fischereder M: Chemokines and chemokine receptors in renal transplantation - from bench to bedside. Acta Physiol Hung 2007; 94:67-81.

39 Krüger B, Böger CA, Obed A, Farkas S, Hoffmann U, Banas B, Fischereder M, Krämer BK: RANTES/CCL5 polymorphisms as a risk factor for recurrent acute rejection. Clin Transplant 2007;21:385-390.

-40 Ruster M, Sperschneider H, Funfstuck R, Stein G, Grone HJ: Differential expression of beta-chemokines MCP-1 and RANTES and their receptors CCR1, CCR2, CCR5 in acute rejection and chronic allograft nephropathy of human renal allografts. Clin Nephrol 2004;61:30-39.

41 Schröppel B, Zhang N, Chen P, Chen D, Bromberg JS, Murphy B: Role of donor-derived monocyte chemoattractant protein-1 in murine islet transplantation. J Am Soc Nephrol 2005;16:444-451.

-42 Grandaliano G, Gesualdo L, Ranieri E, Monno R, Stallone G, Schena FP: Monocyte chemotactic peptide-1 expression and monocyte infiltration in acute renal transplant rejection. Transplantation 1997;63:414-420. 
43 Woltman AM, de Fijter JW, van der Kooij SW, Jie KE, Massacrier C, Caux C, Daha MR, van KC: MIP-3alpha/CCL20 in renal transplantation and its possible involvement as dendritic cell chemoattractant in allograft rejection. Am J Transplant 2005;5:21142125.

44 Dubinski B, Boratynska M, Kopec W, Szyber $\mathrm{P}$, Patrzalek D, Klinger M: Activated cells in urine and monocyte chemotactic peptide-1 (MCP-1) - sensitive rejection markers in renal graft recipients. Transpl Immunol 2008; 18:203-207.

-45 de Groot K, Kuklik K, Bröcker V, Schwarz A, Gwinner W, Kreipe H, Haller H, Fliser D, Mengel M: Toll-like receptor 2 and renal allograft function. Am J Nephrol 2008;28: 583-588.

46 Deng JF, Geng L, Qian YG, Li H, Wang Y, Xie HY, Feng XW, Zheng SS: The role of toll-like receptors 2 and 4 in acute allograft rejection after liver transplantation. Transplant Proc 2007;39:3222-3224.
47 Banas MC, Banas B, Hudkins KL, Wietecha TA, Iyoda M, Bock E, Hauser P, Pippin JW, Shankland SJ, Smith KD, Stoelcker B, Liu G, Grone HJ, Kramer BK, Alpers CE: TLR4 links podocytes with the innate immune system to mediate glomerular injury. J Am Soc Nephrol 2008;19:704-713.

48 Ning Q, Sun Y, Han M, Zhang L, Zhu C, Zhang W, Guo H, Li J, Yan W, Gong F, Chen Z, He W, Koscik C, Smith R, Gorczynski R, Levy G, Luo X: Role of fibrinogen-like protein 2 prothrombinase/fibroleukin in experimental and human allograft rejection. J Immunol 2005;174:7403-7411.

49 Krüger B, Krick S, Dhillon N, Lerner SM, Ames S, Bromberg JS, Lin M, Walsh L, Vella J, Fischereder M, Krämer BK, Colvin RB, Heeger PS, Murphy BT, Schröppel B: Donor Toll-like receptor 4 contributes to ischemia and reperfusion injury following human kidney transplantation. Proc Natl Acad Sci USA 2009;106:3390-3395.

50 Chen A, Sheu LF, Ho YS, Lin YF, Chou WY, Chou TC, Lee WH: Experimental focal segmental glomerulosclerosis in mice. Nephron 1998;78:440-452.
1 Cunningham MA, Ono T, Hewitson TD, Tipping PG, Becker GJ, Holdsworth SR: Tissue factor pathway inhibitor expression in human crescentic glomerulonephritis. Kidney Int 1999;55:1311-1318.

52 Cunningham MA, Kitching AR, Tipping PG, Holdsworth SR: Fibrin independent proinflammatory effects of tissue factor in experimental crescentic glomerulonephritis. Kidney Int 2004;66:647-654.

53 Lai PC, Smith J, Bhangal G, Chaudhry KA, Chaudhry AN, Keith JC Jr, Tam FW, Pusey $\mathrm{CD}$, Cook HT: Interleukin-11 reduces renal injury and glomerular NF-kappa B activity in murine experimental glomerulonephritis. Nephron Exp Nephrol 2005;101:e146-e154.

$54 \mathrm{He}$ H, Stone JR, Perkins DL: Analysis of robust innate immune response after transplantation in the absence of adaptive immunity. Transplantation 2002;73:853-861.

55 Christopher K, Mueller TF, Ma C, Liang Y, Perkins DL: Analysis of the innate and adaptive phases of allograft rejection by cluster analysis of transcriptional profiles. J Immunol 2002;169:522-530. 